\title{
Sanctification Through Knowledge and Imitation in Philippians
}

\author{
Miroslav Balint-Feudvarski \\ Baptistička crkva Radosne vijesti, Nova Gradiška \\ mbalint.feudvarski@gmail.com
}

UDK: 2.182:27-246

Original scientific paper

https://doi.org/10.32862/k.12.1.2

\begin{abstract}
Throughout the New Testament, we find exhortations to imitate or follow in the steps of Christ, Paul and even some other godly people. In the Epistle to the Philippians, we find this exhortation to imitate incorporated into a Pauline theology of progressive sanctification. Sanctification in Philippians is portrayed as a conforming to Christ through the knowledge of Him, which comes through tripartite means of the Word of God (the Apostolic teaching), the internal work of God's Spirit and the imitation of Christ, the Apostle Paul and other godly examples. We will aim at forming a biblical theology of sanctification through imitation restricted in our analysis to the Epistle of Philippians. First part of the article reviews the teaching of sanctification in Philippians, with an emphasis on passages where Paul directly addresses this issue: Philippians 1:9-11, 27-29; 2:12-16; 3:1-15. Second part of the article introduces us to biblical teaching on imitation, and then it reviews a downward spiral of imitation: imitating Christ (Phil. 2:5), imitating Paul (Phil. 3:17a; 4:9) and imitating Paul's faithful imitators (Phil. 3:17b). In the conclusion, we will see that imitation of Christ and His faithful imitators is a means of progressive sanctification that is both important and often neglected, both by those who should serve as primary examples of godliness (spiritual leaders) and those who need to learn by imitating.
\end{abstract}

Key terms: imitation, sanctification knowledge, transformation, model, Christ, Paul, Philippians, Holy Spirit, Scriptures 


\section{Introduction}

Human beings are created to be imitators. From their earliest age, they learn behavior, speech, and even attitudes by imitating first their parents and siblings, and then from other people. God created humans in His own image, and this most likely pertains to their "function of exercising dominion over the rest of the created order" (Allison and Castaldo 89). In other words, human beings are to imitate God's all-encompassing rule and dominion on the earth. When humans fell into sin, they did not cease to be imitators. Their capacity only increased to include not only good but also bad examples. Moses was aware of this when he warned Israelites, "When you enter the land which the Lord your God gives you, you shall not learn to imitate the detestable things of those nations" (Deut. 18:9). ${ }^{1}$ In the culture of Paul and his readers, both Jewish and Greek students "cared about their teacher's lifestyle, which they normally sought to imitate" and therefore were eager to "preserve the deeds and character of their masters as well as their teachings" (Keener 32). That it was expected of students to imitate their teachers is clear even from the negative comment of Christ "therefore all that they (Pharisees and Sadducees) tell you, do and observe, but do not do according to their deeds; for they say things and do not do them" (Matt. 23:3).

Scriptures call Jesus "the image of the invisible God" (Col. 1:15), and He himself said that He is imitating his Father (Jn. 5:19). This is very interesting in light of the teaching of Scriptures that the goal of Christian life, indeed the goal of salvation, is to be conformed to the image of Christ (Eph. 4:24; Rom. 8:29; $1 \mathrm{Jn}$. $3: 2$ ). It is not surprising then that Scriptures also broaden this image of imitation from imitating Christ to imitating other godly examples as well. One of the most extensive invitations to imitation can be found in the Epistle to the Philippians. This article will attempt to examine the teaching of this Epistle regarding believer's sanctification, and then explore its connection to the exhortations to imitate Christ, Paul, and other believers also.

\section{Sanctification in Philippians}

In the Pauline corpus, sanctification may be divided into three different yet connected concepts. Thomas Schreiner notes that while "often sanctification is understood only in terms of progressive growth in the Christian life," "Paul typically indicates God's definitive setting aside work at conversion," for example in 1

1 All Scripture quotations are taken from New American Standard Bible: 1995 Update. LaHabra, CA.: The Lockman Foundation, 1995, unless specifically noted. 
Corinthians 1:2 where he calls the Corinthians "sanctified in Christ" (Schreiner 372-3). Paul also uses this word for "the ongoing work of holiness in the lives of believers" (Schreiner 374). Finally, according to Paul, sanctification is also an eschatological reality, since it includes the consummation of holiness, when "God will sanctify them completely (1 Thess. 5:24)" (Schreiner 375). Pauline doctrine of sanctification follows the "already-not yet dimension of Paul's eschatology" (Schreiner 375). This means that, in Paul's thoughts, these three concepts of sanctification are interrelated. We will see how this plays out in his Epistle to the Philippians.

\section{God is the Author and Perfecter of Eschatological Sanctification}

At the very beginning of his Epistle, Paul finds his utmost reason for thankfulness to God for Philippians in his assurance that God will perfect or finish the "good work" that He has started in or among them (O'Brien 63). Many commentators agree that this "good work" is their salvation (Calvin 26) or more specifically sanctification, ${ }^{2}$ although not everybody thinks that this good work is soteriological. ${ }^{3}$ Peter O'Brien in this verse sees an allusion to Genesis 1-2, where God's work is described as good. He thinks that Paul also alludes to the book of Isaiah, where God is designated as "the First and the Last" in Isaiah 41:4; 44:6; 48:12, in His activity as a creator of Israel (O'Brien 64-65). Therefore, Paul is here teaching that God is the author and perfecter of believer's salvation, ${ }^{4}$ and some commentators are even indicating a progressive nature of perfecting this good work, so they translate the future tense of $\dot{\varepsilon} \pi i \tau \varepsilon \lambda \varepsilon^{\prime} \omega$ as "He will lead it towards the completion, and He will finally perfect it." ${ }^{5}$ In any case, progressive ideal is at least implied. If O'Brien is right that Paul is alluding to Genesis $1-2,{ }^{6}$ we can conclude that sanctification is a constituent part of this process of transformation into "the new self, which in the likeness of God has been created in righteousness and holiness of the truth" (Eph. 4:24).

2 Cf. Witherington 2011, 60; Spurgeon 2014, 11.

3 Some think that Paul is here speaking of some specific work that God is doing in the church in Philippi (Foulkes 1250) or that God will accomplish the mission of evangelism in Philippi until Christ returns (Lightfoot 84). However, it is better to see the participation of Philippians in evangelism as a fruit of God's working in them, not as means to an end (O'Brien 64).

4 Cf. Heb. 12:2 where Lord Jesus is called "the Author and Perfecter of faith."

5 Rogers 1998, 448; Hendriksen 1964, 54; contra Wallace, "Wedged as it is between the past

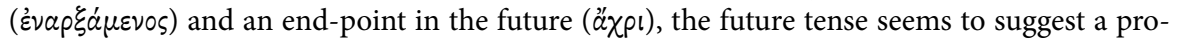
gressive idea. But the future in itself says none of this" (Wallace 568).

6 An allusion that commentators in the Commentary on the New Testament Use of the Old Testament did not catch. 
That transformation will not end before nor after, but on the day of Christ Jesus (Phil. 1:6). We will see this truth again in Philippians 3, where Paul states that all who are perfect ${ }^{7}$ know that they are still not perfect, namely that they still did not reach that condition of perfect righteousness and holiness. Paul used several expressions to describe that state of being. In Philippians 3:11, he calls it resurrection from the dead and in 3:12 he connects it with the accomplishment of perfection. In 3:14, Paul is pressing toward attaining the upward call of God in Christ Jesus. Here we have an interesting example of theological tension, between Paul's effort to attain the upward call, perfection or resurrection from the dead (that can be compared with the effort that a runner is giving towards winning the prize), and a clear teaching that he will not be able to attain this state of being before Christ's return. Indeed, it is an upward call (heavenly call according to NRSV), and in Philippians 3:18-19 he is correcting those who might think that they have already attained the perfection, probably those who are putting their confidence in the flesh and are content with the present earthly state of being. ${ }^{8}$ After this warning, Paul almost bursts into doxology in 3:20-21,

"For our citizenship is in heaven, from which also we eagerly wait for a Savior, the Lord Jesus Christ; who will transform the body of our humble state into conformity with the body of His glory, by the exertion of the power that $\mathrm{He}$ has even to subject all things to Himself."

Ralph Martin claims that Paul is here alluding to twin citizenship of those living in Philippi, considering themselves to be primarily citizens of Rome, who live in Roman colony in Philippi (Martin 129). Surely, Paul is not the only one to describe Christians' homeland in heaven. ${ }^{9}$ Roman citizenship of Philippians is, in any case, a good illustration of the already-not yet tension in the believer's life. They

7 This is probably one of Paul's puns, because adjective $\tau \dot{\varepsilon} \lambda \varepsilon$ cloৎ also means mature.

8 Paul here does not elaborate on theology of those who think they have reached the perfection. I presume that their critique is leveled against those about whom he warned Philippians about at the beginning of chapter 3. It is interesting to compare this with Gordon Fee's comments in his commentary on 1 Corinthians, where he describes deviant Corinthian theology as an “'over realized' eschatological view of their present existence", naming this view "spiritualized eschatology" (Fee 12). Fee writes that those in Corinth who had this spiritualized eschatology thought "of themselves as having already realized the 'resurrection from the dead" by being in spirit and thus already as the angels" (Fee 269), that they disregarded "some very customary distinctions between sexes" (Fee 498) and "denied the value/significance of the body" (Fee 716). They also despised Paul "whose weaknesses make it obvious that he had not arrived" (Fee 12).

9 Cf. Heb. 11:16, where believers are groaning after their heavenly homeland, and God prepared a city for them, the same city that, in Rev. 21:2, comes down from heaven to rest upon the New Earth. 
are already citizens of heaven, yet they life on Earth in that which Paul calls the body of our humble state (v. 21). Paul is here describing what elsewhere he calls glorification ${ }^{10}$ as the transformation of the body of our humble state and says that Christ will conform it with the body of His glory. In 2 Corinthians 11:13-15, the verb $\mu \varepsilon \tau \alpha \sigma \chi \eta \mu \alpha \tau i$ ' $\omega$ describes Satan's crafty transforming into an angel of light and false teacher's transformation into apostles of Christ, but here Paul describes it further with an adjective $\sigma u ́ \mu \mu \rho p \phi o s$ that is denoting conforming or assimilating to Christ's glorified body.

\section{God is the Author and Effectuator of Progressive Sanctification}

Therefore, we have seen that believers have a hope in final sanctification (glorification) when their bodies of humble state ${ }^{11}$ will become identical to the body of Christ's glory in all its moral beauty and perfect holiness. We have seen a plausible interpretation of Philippians 1:6, whereby Paul believed that God did not only start the good work of salvation among Philippians with their definitive sanctification, sanctification that will be picked up when Christ returns to finally conform them to Himself, but that he was also certain in their progressive sanctification. De facto, their continual sanctification, which they manifested with their participation in spreading the Gospel $(1: 5,7 ; 2: 30 ; 4: 3)$, their obedience to Paul (2:13) and even their financial gifts towards Paul's ministry (4:10-19), becomes the ground for his certainty $(1: 6)$ that God is working in their lives. ${ }^{12}$

Nevertheless, church in Philippi was far from being an ideal church. On the inside, this church was not united, which is why Paul emphasizes unity, concord and humility $(1: 27 ; 2: 1-4 ; 4: 2-3)$. Such unity and humility are marks of a church that is behaving "worthy of the Gospel of Christ," (1:27) which works out its salvation in practice (2:12) and where God is active in their sanctification (2:13). Paul is stimulating them to fight thus united for the "faith of the Gospel" (1:27; $2: 16$ ). Such disunity and rivalry in the church make her vulnerable to the attacks from the outside. Paul's promptings towards sanctification with its description

10 In his commentary on Romans, Douglas Moo shows that this passage is parallel to Rom. 8:2830 , where God's main purpose of predestination, namely for believers to be conformed to the image of His Son, is called glorification (Moo 535).

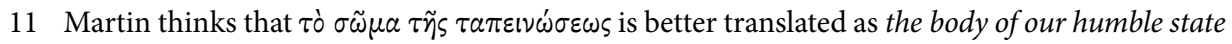
(NASB), not as our lowly bodies (NIV), because then we can see the connection to Christ's humbleness in Phil. 2:8 (Martin 131). Implications of such connection are rich and play a similar role to Paul's use of 2 Cor. 8:9 in his encouragement to Corinthians to be generous to poor believers in Judea, "For you know the grace of our Lord Jesus Christ, that though He was rich, yet for your sake He became poor, so that you through His poverty might become rich."

12 We can find a similar certainty in 1 Thess. 1:4-10, where repentance and ministry of Thessalonians to God serve as an indication to Paul that they were chosen by God. 
come to them in the context of those inside rivalries and outside attacks.

Now we will focus on specific passages where Paul talks about progressive sanctification, with a special emphasis on God's incentive and the knowledge of Christ in sanctification.

\section{Paul Prays for Their Growth in Knowledge (Phil. 1:9-11)}

In this passage, Paul prays for Philippians and we witness his care and deep understanding of his friend's spiritual needs. He thinks about them, understands their problems and prays for them. These are definitely points for prayer that we can take with us to our next prayer meeting, as well as things that are definitely according to God's will.

Since Paul is not rebuking any fraction in Philippi for any glaring sin or heresy, ${ }^{13}$ we are safe to assume that quarrels between believers in this town were of a more personal nature or preferences. It is very interesting that Paul mentions "the overseers and deacons" in his greeting, something that he did not do in his other canonical Epistles. Is it possible that overseers and deacons were the ones who have addressed the whole issue about the rivalry in the church with Paul, so it would mean that the Epistle also serves as a silent exhortation to the church to surrender to their loving authority? ${ }^{14}$

Paul is praying that their love would abound more and more in real or complete knowledge and all discernment. Real knowledge ${ }^{15}$ does not have an object, but we are able to conclude, from the usual use of that word in other Pauline writings and from the context of this Epistle (Phil. 3:8) that he is talking about real and growing knowledge of God through Christ. All discernment is about the "ability to make proper moral decisions in the midst of a vast array of differing and difficult choices" (Rogers Jr. and Rogers III 449). Such a knowledge and discernment which inform and build up love will help them to discern what is better. In other words, by their decisions and deeds they will show themselves

13 It seems that Judaizers in Phil. 3:1-15 were not members of the church in Philippi, and some commentators believe that they were at that time only a potential threat and "yet had not made serious inroads into the life of the congregation" (O'Brien 354).

14 It is probably not a mere coincidence that in Carmen Christi (Phil. 2:6-11) Christ sets an example of a humble submission to authority, despite His equality with God, and therefore despite their Christian equality. Paul gives them another exhortation to submission in Phil. 2:12, as well as one to do all things "without grumbling or disputing" (v. 14). Also, it is at least possible that Paul's faithful friend in Phil. 4:3, who was to help Euodia and Syntyche to reconcile, was one of the overseers (Witherington III 237). Therefore, it is plausible that it is exactly these overseers and deacons, among others, who "walk according to the pattern you have in us" (Phil. 3:17) and whose example Paul wanted Philippians to follow.

15 For a review of different interpretations of $\dot{\varepsilon} \pi i ́ \gamma \nu \omega \sigma \iota \varsigma$, cf. O’Brien 1991, 76. 
sincere and blameless on the Day of Christ, and their fruit of righteousness that comes through Jesus Christ ${ }^{16}$ will be unto the honor and glory of God.

\section{Paul Encourages Them to Live Worthy of Christ's Gospel (Phil 1:27-29)}

This section begins with an instruction that Philippians should conduct in a manner worthy of the Gospel of Christ. Adjective á $\xi i \omega s$ (worthy) in the NT designates conforming one's behavior to a certain standard that is set as an example. ${ }^{17}$ Here that standard is Gospel of Christ, which reflects Christ's nature and His will. ${ }^{18}$ To walk in a manner worthy of Christ's Gospel means to behave in accordance with the example of Christ, which Paul will soon describe in Philippians 2:6-9, but also in accordance with the privileges He achieved for us through His life, death, and resurrection (Phil. 3:10; cf. Gal. 2:19-20). Paul stresses our unity with Christ in His sufferings, while "standing firm in one spirit, with one mind striving together for the faith of the gospel" (1:27). They are also united with Paul in the same "conflict" (v. 30). We should notice that Paul is able, in the same Epistle, to encourage believers to fight for the gospel, while also exhorting them to be humble (2:3) and lovely (4:8). This reminds us of Jesus, who was ever gracious to His listeners, while acting in a bold and straightforward way. ${ }^{19}$ To be humble and gracious does not mean to water down the truth, but to speak the truth in love (Eph. 4:15).

\section{Paul Exhorts Philippians to Work Out Their Salvation (Phil. 2:12-16)}

After he exhorted them to be united and humble (2:1-4) and after Christ's superb example of humble submission and resultant exaltation (2:5-11), Apostle exhorts his readers in v. 12 to work out their salvation "with fear and trembling." Several interesting insights capture our attention. First, working out salvation with fear and trembling seems to be at odds with Paul's assurance in 1:6 that God will finish His good work in believers which He started. At the very least, Christian's

16 Cf. Phil. 3:9 with Gal. 5:22-26, which ends with similar incentives that we find in Phil. 2:1-4.

17 Rom. 16:2, manner worthy of the saints; Eph. 4:1, manner worthy of the calling; Col. 1:10, manner worthy of the Lord; 1 Thess. 2:12, manner worthy of God; 3 Jn. 6, manner worthy of God; and here.

18 Compare Matt. 11:28-30, where Jesus is calling us to learn from his humbleness and meekness. His teaching reflects his nature. Also, Rom. 6:17 where, according to George Zemek, "new teaching, i.e. the message of Christ, is the factor which stamps and determines the life of the Christian" (Zemek 254).

19 John Crotts does a good job in explaining those times when Jesus did not seem gracious to people, "When Jesus communicated intensely with others, He was never sinfully angry; rather, He was motivated by defending and declaring the glory of God. When Jesus was personally attacked, He was gracious, even when He was reviled on the cross, but when God's glory or His divine purposes in His mission as Messiah were at stake, He answered boldly" (Crotts Kindle loc. 534). 
assurance does not mean that he does not pursue his sanctification. The author of Hebrews warned believers to pursue "the sanctification without which no one will see the Lord" (Heb. 12:14). Paul's expression with fear and trembling does not need to mean that Paul is exhorting them toward an unhealthy fear of God, trembling over the possibility of their eternal damnation or fearing God's rejection. On the contrary, Paul is exhorting them toward "an attitude of due reverence and awe in the presence of God, a godly fear of the believer in view of the final day" (O'Brien 238). ${ }^{20}$ It is also possible that Paul wanted to make a contrast in his exhortation to Philippians that they should not be afraid of their opponents, ${ }^{21}$ but to have a healthy fear and awe before the Lord, the fear which casts out the fear of people. (Welch 95-134) Or better yet, in view of Isaiah 6:5-7, we could say that this fear and trembling is the primary and spontaneous reaction to God's holiness, before taking into view the forgiveness we were granted. It is as if the Scriptures want to say that believers should never lose this fear and trembling, but in view of salvation, they should also never remain in it for too long (cf. 1 Jn. 4:17-18). In any case, this expression means that every Christian should approach his or her salvation seriously (cf. Gal. 6:7 ff.).

Second, working out salvation with fear and trembling needs to be interpreted in the light of Paul's assurance in the very next verse, "for it is God who is at work in you, both to will and to work for His good pleasure" (v. 13). In other words, God who "began a good work in you" and who will "perfect it until the day of Christ Jesus" (1:6), is also "at work in you" (2:13). Inserting fear and trembling in this equation seems to rescue us from spiritual lethargy and sluggishness, at the same time discouraging our self-confidence and unhealthy obsession with our own salvation. It exhorts us to put our faith and confidence in God, and rely solely on Christ for salvation, while also cooperating with God's Spirit in everyday sanctification and service. ${ }^{22}$

There is some debate as to what does work out your salvation ( $\dot{\varepsilon} \alpha \tau \tau \tilde{\omega} \nu \sigma \omega \tau \eta p^{\prime} \alpha \nu$

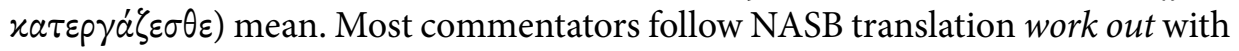
the meaning "to carry out to the goal, to carry to its ultimate conclusion... Christlikeness" (Wuest Phil. 2:12). On the other hand, Peter O’Brien lists several interpretations which argue that " $\sigma \omega \tau \eta p^{\prime} a$ is being used in a sociological rather than a strictly theological sense, to describe the spiritual health and well-being of the entire community at Philippi" (O’Brien 277). Nevertheless, he rejects those views

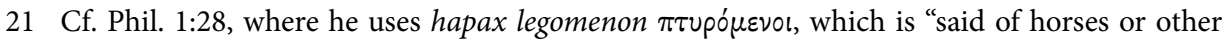
animals startled or suddenly scared” (Jamieson, Fausset and Brown 362).

22 We see that the Spirit is God's agent of sanctification in these and other verses: 2 Cor. 3:18; Gal. 3:5; Eph. 3:16; 1 Pt. 1:2. 
and gives forth his own view that Paul "urging the Philippians to show forth the graces of Christ in their lives, to make their eternal salvation fruitful in the here and now as they fulfil their responsibilities to one another as well as to nonChristians" (O’Brien 280). Ben Witherington does agree with O’Brien that Paul is talking about theological salvation, but he differs from him in that he thinks that Paul "is talking about the community helping one another work out their personal salvation" (Witherington III 159).

Thomas Schreiner, on the other hand, goes as far as paraphrasing the command as accomplish your own salvation and claims that "the verb simply means 'work, accomplish' or 'do"' (Schreiner 256). Nevertheless, he explains that "this call to accomplish salvation does not fall prey to works-righteousness, nor does it commend human autonomy" since their "obedience... is energized by God" (Schreiner 657). He differentiates between righteous behavior which "though not the ground of salvation - is utterly necessary to obtain salvation" (Schreiner 226). Thus, he claims that believers do obtain their salvation, but they do not "merit their own salvation" since they are "already forgiven of their sins" (Schreiner 257). Therefore, it seems that the most compelling two views, those of Schreiner and O'Brien, dispute whether we are to work on our salvation by working out our sanctification (Schreiner) or to work on our sanctification and thus work out our salvation (O'Brien). They both seem to put a great emphasis on both God's power accomplishing sanctifying work in believers and the responsibility of believers to actively participate. In the light of that, we may conclude that Paul is exhorting believers to work on their progressive sanctification with a view of their eschatological sanctification as a goal towards which they should be striving.

We must not overlook the important connection of this working out of salvation and obedience to Paul as their spiritual leader. ${ }^{23}$ We cannot devoid our obedience to God from the authoritative voice of God which we find in Scriptures, written by His Apostles and Prophets (Eph. 2:20; 2 Thess. 3:14), but also from submitting to godly authority of our elders (Heb. 13:17), older Christians (1 Pt. 5:5) and one another in general (Eph. 5:21). We are safe to conclude that Paul sees this obedience as another means of sanctification.

\section{Paul Describes Sanctification as Growth in the Knowledge of Christ (Phil} 3:1-15)

This paragraph starts with an imperative we meet often in this Epistle, "Rejoice in the Lord!" He is encouraging believers to rejoice despite their circumstances, namely captivity of their spiritual father (Phil. 2:12, 17-19), their everyday

23 Schreiner pointed this out to me in a comment he wrote when he reviewed my paper for his class in New Testament Theology in 2010. 
needs and quarrels (4:4), confronting the opponents of the Gospel (3:1 ff.) and the setbacks in their sanctification (3:12-13). Paul is warning Philippians about the Judaizers, who were advocating that Gentile believers should be circumcised and obey Moses' Law (Gal. 5:2-10). In Galatians 6:14, Paul calls Christians God's Israel, and in Philippians 3:3 he calls them the circumcision and puts them in opposition to those who mutilate the flesh. Paul points out two marks of true Christians. First, their worship is prompted by the Spirit of God. ${ }^{24}$ The verb $\lambda a \tau \rho \varepsilon v^{\prime} \omega$, worship, has the meaning of worship of God, but in this verse, it seems to be a synonym for a life of sanctification (cf. Rom. 12:1-2; Heb. 9:9, 14; 12:28). Furthermore, true believers boast in Christ Jesus and they have no confidence in the flesh. In Philippians 3:4-6, Paul argues according to folly (Prov. 26:5), by comparing himself with anyone who wants to put confidence in the flesh. It is important to realize that Paul is not saying that he could really put confidence in his flesh for salvation (cf. Gal. 2:15-16), but that he can be a sparring partner to anyone who would want to do that.

Knowledge of Christ Jesus in 3:7-8, is said to be of surpassing value. That knowledge was so valuable to him, that he suffered loss and sacrificed everything that he "may gain Christ and may be found in him" (v. 8). This is all about the cost of discipleship which Paul is willing to pay, and not about the merit by which a man is coming to Christ, because Paul adds, "not having a righteousness of my own derived from the Law, but that which is through faith in Christ, the righteousness which comes from God on the basis of faith" (v. 9). This knowledge of Christ Jesus is comprehensive, because it encompasses Himself and the power of His resurrection, the fellowship of His sufferings and conforming to His death. Paul gives his readers an example of having the same attitude that he saw in Jesus, an attitude of humility and self-sacrifice (cf. Phil. 2:5). In other words, Paul himself is learning from Christ and he considers others more important than himself by sacrificing his life for them in obedience to the Lord. ${ }^{25}$ He does all of this "in order that I might attain to the resurrection from the dead" (v. 11). Verb

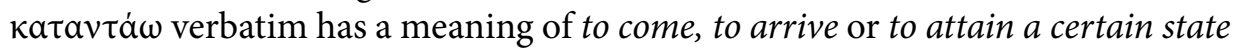
of being, (Swanson GGK2918) and it does not mean to earn. Paul further describes this state of being as (being) perfect, ${ }^{26}$ (v. 12) and as a prize of an upper call (v. 14). The same verb is used by Paul in 1 Corinthians 9:24 for the prize that was given to the runner that would come first. In 2 Timothy 4:7, a finished race me-

24 Noun $\pi \nu \varepsilon \dot{\mu} \mu a \tau ı$ can be an instrumental dative, with the meaning worship with the Spirit or worship prompted by the Spirit. Cf. Wallace 1996, 158-171.

25 Cf. Phil 2:17 where Paul says that he is sacrificing for their faith. Also Acts 9:16 where Paul was to suffer for Christ's name sake.

Cf. Lk. 13:32, where Jesus is connecting the resurrection to becoming perfect. 
ans to keep the faith until the end. In Hebrews 12:1-3, the author is speaking of a race in which we have to discard every encumbrance and sin. Again, our example in this race is Lord Jesus Himself, who is the Author and Perfecter of faith, who endured the cross and endured such hostility by sinners against Him.

Therefore, Paul gives an example of striving to carry out this knowledge of Christ in practice (Phil. 3:8), through spiritual conformation to the image of the Lord (cf. 2 Cor. 3:18). He himself was striving to conform his own life here on earth more and more to the resurrected state of perfection. Nonetheless, Paul was standing, as it were, with both feet on the ground, knowing that he will not be able to reach this state of being during his lifetime (Phil. 3:12-13, 15-16). Yet, that did not discourage him to keep striving and progressing.

In conclusion, we can say that Paul was clearly teaching Philippians that sanctification is a progressive transformation into the image of Christ, brought about through the knowledge of Christ and with the incentive and power of God's Spirit. Progressive sanctification is a reality which believers are enjoying already, in the hope of future glorification, which currently is still not yet. Their sanctification will become perfect with the resurrection from the dead, that is, on the Day of Christ. Paul is describing that day in Philippians 3:20-21, when the Lord "will transform the body of our humble state into conformity with the body of His glory, by the exertion of the power that He has even to subject all things to Himself".

\section{Sanctification Through Imitation of Godly Examples}

Until now, we were discussing the vertical dimension of believer's transformation into the image of Christ. We are transforming into the image we observe through the Word and the Spirit, striving with Paul to know, gain and be found in Christ (Phil. 3:8-9). Nevertheless, there is also an important and often neglected horizontal dimension of this transformation. As one author wrote, "How are Christ believers supposed to follow a man we've never met?" (Reeves 243). Paul and the other Apostles were aware of this problem, and to the above duality of Word and Spirit as the means of this transformation into the image of Christ, they often added another dimension: imitation!

\section{A Call to Imitation}

The Bible is exhorting us to imitate Christ. Christ invited His disciples to learn from Him (Matt. 11:28-30). First Christians were primarily called disciples, and the disciple's task is to "observe all that I commanded to you" (Matt. 28:20), but also to follow in His steps (1 Pet. 2:21). Jesus literally invited His disciples to fol- 
low Him, walking in His footsteps on those dusty roads of Galilee, Samaria and Judea, observing His example. It is interesting that a life of faith and obedience is often portrayed with the Greek word that literally means to walk $\left(\pi \varepsilon \rho l \pi \alpha \tau \varepsilon^{\prime} \omega\right)$. This call to imitation is inseparably tied to discipleship. ${ }^{27}$ Epistle to Philippians is certainly exhorting us to follow Christ's example (Phil. 2:5). Nonetheless, when talking about imitating Christ, it can become a problem if we think about Christ only as a man of God whose moral example we are capable of following on our own. Alister McGrath (292) warns us about this external imitation, "This form of exemplarism invites us to believe in Jesus Christ as an example who shows us, as one who is outside us and historically distant from us, what ought to be done. But he is unable to transform the tragic situation of humanity in order that it can be done".

In other words, our doctrine of imitation of Christ largely depends and should be consciously connected to our doctrine of sanctification. Imitation of Christ does not so much consist of thinking What Would Jesus Do in a certain situation, but it consists of growth in true and all-encompassing knowledge of Jesus Christ that is manifested in His attitudes, which Paul calls the fruit of the Spirit in Galatians 5:22.

\section{Imitating Christ (Phil. 2:5)}

Paul's sole direct exhortation to imitating Christ both confirms and informs such a view of sanctification as conformation to Christ's image. Literal translation of this verse would be: "Think this in you which also in Christ Jesus." Obvious lack of a second verb brought about different interpretations of this verse. Ralph Martin, "Have this opinion among you as you think in Jesus Christ, i.e. as members of His church" (Martin 75-76). ${ }^{28}$ Nevertheless, J. B. Lightfoot gives a better interpretation, "Reflect in your minds the mind of Christ Jesus. Be humble as $\mathrm{He}$ also was humble" (Lightfoot 110). ${ }^{29}$

The verb фpov'́ $\omega$ in this context means "have thoughts or (an) attitude(s), be minded or disposed" (Bauer, Arndt and Gingrich 874), and present tense "implies a continual, habitual attitude" (Rogers Jr. and Rogers III 451). Therefore, a good translation would read, "May this attitude be in you as it was in Christ Jesus." This helps to keep the function of this verse as a joint that ties exhortations to humbleness, seeking each other's interests, love and unity (Phil. 2:1-4) with

27 I am thankful to Ervin Budiselić who pointed this out to me in his review of the first draft of this article.

28 Hendriksen 1964, 102, in footnote number 30 refutes this view. 
Christ's exalted attitude of humility and obedience (2:5-11). ${ }^{30}$ Indeed, all exhortations to sanctification in this Epistle in one way or other find its inspiration in Christ's example in Phil. 2:5-11. Again, Christ's example to believers serves not as an illustration which they should emulate mechanically. It is God who will perfect this "good work" of conforming to Christ until His return (Phil. 1:6). Spirit of Jesus Christ gives Paul all the necessary provision in his bonds (1:19), so that he can do everything in God that empowers him (4:13). ${ }^{31}$ It is God who produces both to will and to work in Philippians (2:13). Finally, God's people consist of those who are being sanctified with the incentive and power of the Spirit of God, of those who do not rely upon their natural abilities (3:3).

Therefore, sanctification that the Apostle is describing as imitation of Christ's example and conforming through the knowledge of $\mathrm{Him}^{32}$ is not some legalistic following after some external laws but conforming to the image of Christ in the power of the Holy Spirit. ${ }^{33}$

\section{Imitating Apostle Paul (Phil. 3:17a \& 4:9)}

The entire Epistle to the Philippians is saturated with Paul's example of living in Christ. Although Christ is, as Zemek calls him, the Archetype and the Exem-

30 However, I believe that Apostle implies much more in Christ's example, namely all those virtues that he is encouraging his readers to nourish. Therefore, Christ also did not seek His own interests, but His Father's and of the elected ones. Christ had the same love towards the world as Father did (Jn. 3:16), so He gave his own life as a ransom. Christ fought for the "faith of the Gospel" (Phil. 1:28) holding fast the word of life (2:16). Finally, apostle calls Philippians to conform with Christ even with regards to His exaltation. Not only did His exaltation through resurrection safeguard their own resurrection to glory, yet we also have to imitate Christ's attitude of yielding to God the Father to exalt Him in due time. Philippians are called to imitate that attitude primarily by not being anxious about anything, but let their needs be known to God through prayer (4:6; but cf. connection between casting all your anxiety on God and exaltation at the proper time in 1 Pt. 5:6-7).

31 Here, in Phil. 1:6 and in 2:13 Paul uses participles to describe God: He who started, He who works in you and He who empowers. All these participles become personal nouns for God, and they reveal something about God's nature with regards to our Christian life and sanctification.

32 Cf. 1 Jn. 3:2 where Apostle John describes glorification as a moment when we will be like Jesus because we will see Him as He is. In other words, it is then when our knowledge will become complete and when our Lord will, to borrow the expression from Phil. 3:21, transform our humble state into conformity with the body of His glory.

33 Christ's example of inward attitudes therefore becomes for the believer what Paul calls in other places "the Law of Christ" (cf. 1 Cor. 9:21, and especially Gal. 6:2 where Paul says that we fulfill Christ's Law by bearing one other's burdens). William Hendriksen says, "This law of Christ is the principle of love for one another laid down by Christ ... However, Christ not only promulgated this law; he also exemplified it (Hendriksen 233). 
plar, or, in other words, our model par excellence who "alone displays the perfect moral image of God" (Zemek 264), Paul uses more space in the Epistle to show his own example. Therefore, we are not surprised when Paul invites believers, as he does in his other Epistles, to imitate him in 3:17a, "Together keep being my imitators..." (my own translation). The Apostle uses the noun $\sigma u \mu \mu \mu \eta \tau \eta \dot{s}$ in plural together with the verb $\gamma^{\prime}$ ivoual (become, be), in the present tense: together keep becoming imitators. Since the verb is in the present tense, it signifies a continuous action. The prefix $\sigma v$ - signifies that the Philippians were supposed to do this together, as a community, which would certainly aid their unity. "Mimeimai has the sense of 'to imitate,' 'to mimic', i.e. to do what is seen to be done by someone else" (Zemek 254).

Through his example of spreading the Gospel while imprisoned, the Apostle to the Gentiles encouraged "most of the brethren" to have "far more courage to speak the word of God without fear" (1:14). He primarily lives for Christ (1:21), for His glory (1:20), and his life is supposed to bring fruit of labor (1:22) and advance the faith of the Philippians (1:24-25). Paul never exhorts his children in faith to follow him down a road he himself did not first walk. He exhorts them to always be joyful, despite their worries and problems $(2: 18 ; 3: 1 ; 4: 4)$, however, imprisoned in Rome and expecting a trial, the servant of Christ also rejoices! He rejoices when Christ is preached (1:18) even when that increases the pain of his chains; the unity, love and humility of the Philippians brings him joy (2:2), and he joyfully looks forward to having fellowship with them (2:18). Truly, they are his "joy" (4:1). Paul also rejoices when he received a present from the Philippians (4:10), yet he did not as much rejoice in the present, but in the fact that they have remembered him and have thus gained spiritual profit for themselves (cf. Phil. 4:17).

Paul also serves as an example of the struggle for the faith of the Gospel (1:30, cf. 1:27) which the Philippians were to imitate. He loves them sacrificially and puts their gain ahead of his own (2:17-18, cf. 2:4). Further, he is an example of correct thinking about sanctification (3:2-15), when he draws from his own experience, his own example, and says that believers cannot attain sinless perfection on this side of Parousia. Unlike Christ, Paul is not the model of moral perfection, but an example of a believer who, through God's power, ${ }^{34}$ strives to be more like Christ (3:12-14). ${ }^{35}$ In Philippians 4:9, we see another imperative that Paul uses to

34 But, compare Hebrews 5:8-9 where even Christ as a man had to experientially learn obedience. Of course, that does not mean that he ever sinned.

35 Cf. amazingly similar concept in 1 Corinthians 10:32-11:1, where Paul exhorts Christians not to scandalize anyone, and lists his own example of sacrificial love for others in that he does not seek his own interest but the interest of many, desiring them to be saved. After that, he calls them to imitate him as he imitates Christ. 
invite believers to imitate him, "The things you have learned and received and heard and seen in me, practice these things and the God of peace will be with you." Philippians were supposed to imitate Paul's teaching (learned and received) and his behavior (heard and seen), and as a result, God of peace would be with them. That comes after the well-known passage, where he is teaching them to be anxious for nothing, but to give all their worries to God, whose peace will then keep their hearts and minds in Christ. This same result comes also from imitating Paul's teaching and practice (v. 9)! Therefore, we observe that the Apostle himself was a living example of such confidence in Christ. He does not promise them that the God of peace will be with them because they are following his example, but because in imitating his example (and teaching), they are following Christ (cf. Phil. 2:5 with 2:1 and 4:8).

Paul expected his readers to follow his example; the model of life and ministry they could observe while he was with them, and even that which they can hear about him (1:30). He expected them to follow him as he was following Christ (1 Cor. 11:1). His model primarily refers to the attitudes that were directing his life and service, while encompassing his behavior also.

\section{Imitating Faithful Imitators (Phil. 3:17b)}

When the Lord Jesus told His disciples in Matthew 7:16 that they will know false prophets "by their fruits," he stated the unequivocal truth that we can recognize false (as well as true) believers and preachers by their manner of living. "Every good tree bears good fruit, but the bad tree bears bad fruit" (Matt. $7: 17)$. Bad fruits are a product of a bad tree. The same way the believers need to recognize and stay away from false prophets, they also need to observe and recognize good examples of faithfulness in their local church and in the church in general (for example, reading biographies of men and women of faith). After exhorting Philippians to imitate his example, Apostle redirects their attention to those who "walk according the pattern you have in us" (Phil. 3:17). I have already mentioned the possibility that among those were "overseers and deacons," whom Paul mentions only in this Epistle's opening greetings (1:1). It is possible that one of those overseers were invited to help Euodia and Syntyche to live in harmony.

The believers in Philippi were to look among themselves and seek mature Christians (Phil. 3:15) who were following Paul's example. ${ }^{36}$ They were to carefu-

36 BAG 1957, 837-838, "copy, image, form, figure, pattern, (arche)type, pattern, model, in the moral life example, pattern, of the types given by God as an indication of future, in the form of persons or things." 
lly observe them and imitate their example. ${ }^{37}$ Timothy was certainly one of them (Paul was hoping to send him to them, 2:19) as well as Epaphroditus.

Timothy (Phil. 2:19-23) is portrayed as an example of a believer who honestly cares about Philippians, someone who does not seek his own interests, but the interests of Jesus Christ (v. 21, cf. Phil 2:4). Jesus uses the same word for anxious worry in Matthew 6:31-34, and Paul also uses it later in Philippians 4:6. Timothy cared about the Philippians as intensively as some people wrongfully care about their own needs. He was also serving the Gospel (v. 22, cf. Phil. 1:27; 2:16), while helping Paul as the son helps the father. Epaphroditus (Phil. 2:25-30) was sent to help Paul in prison by Philippians, but he got very sick (v. 27), and found himself close to death for the work of Christ (v. 30, cf. Phil. 1:20; 2:17). Paul calls Philippians to receive him with joy and to respect such people and is probably thinking of him too when exhorting them to observe those who live according to the example he left. ${ }^{38}$

In conclusion, in the Epistle to the Philippians we find the call to imitate the Lord Jesus Christ as a supreme model of humility, sacrificial love, obedience and all other virtues the Apostle called his readers to imitate. Although Paul did not express it as clearly as in 1 Corinthians 11:1, Philippians clearly implies that Paul was calling his spiritual children to imitate him as he was imitating Christ's example. He called them to nurture those internal attitudes of humility, obedience, and sacrificial love that he himself was imitating while observing Christ. In the end, he exhorted them to observe the lives of those who were living according to the example he and his coworkers showed.

\section{Conclusion}

In his satirical song, I Want To Be A Clone, Steve Taylor mocked the legalistic churches who ask for complete uniformity of their members, often being too narrow and intolerant toward any difference from an imagined Christian standard, "Be a clone and kiss conviction goodnight / Cloneliness is next to Godliness, right? / I'm grateful that they show the way / 'Cause I could never know the way / To serve him on my own / I want to be a clone" (Taylor).

While I agree with Taylor's sentiment, nevertheless the Bible is exhorting us towards a certain cloneliness, an imitation of Christlike attitudes and behavior

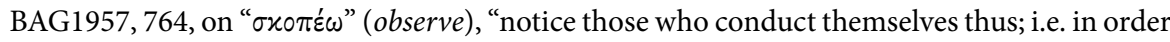
to imitate them". That is observation which requires suitable action. Cf. Rom. 16:17; Gal. 6:1.

38 If the plural, us, in Philippians 3:17 refers to the Apostle and his coworkers, it is possible that Epaphroditus stands together with Paul and Timothy as an example of the Christian life followed by others. 
that we see in others. Biblical emphasis on the indwelling of the Holy Spirit in every believer and enlightening of their mind to understand spiritual truths which are darkened to unbelievers (1 Cor. 2:10-16) can at times be misused in an individualistic over-confidence, coupled with suspicion and even cynicism towards the Church as an institution. When we see all the hypocrisy and failures of the Church to live up to its calling, we can go to the extreme of avoidance of imitation of any kind - even of the avoidance of the church altogether (Keyes 202). We can then attempt to find a spirituality that would always be fresh, a spirituality with a me and my Bible or even me and my YouTube preacher mentality. The problem with that is that we are not only impoverishing ourselves of godly examples of other believers struggling and striving to imitate Christ, but also depriving others of our own struggling and pressing on towards greater Christlikeness!

Christ did not invite us to be clones. We see a great variety in personality even among the Twelve, nevertheless, we also see that they were imitating Christ in His attitudes, graciousness, humbleness and love (for example, compare Phil. 2:5-11 with 1 Pt. 2:21-25). Zemek very aptly expressed that synthesis of sanctification and imitation:

"The primary means of grace in moving the saved along that highway of sanctification is the Word of God attested by the Spirit of God, and a vital constituent of this divine testimony is the incarnate example of Christ. Indeed, $\mathrm{He}$ abides as God's perfect moral manifestation. ... Because of Christ's pattern, the attitude and actions of His people would mature in integrity and consistency of Christlikeness (cf. Phil. 1:27 ff.; 1 Jn. 2:6). As they mature morally, some more rapidly than others, they themselves are to become reflections of His moral model (cf. 1 Thess. 1:7)" (Zemek 252).

In practice, such imitation of moral examples encompasses both thinking and attitudes (Phil. 2:5; 3:15), and behavior (Phil. 3:17). Outside of the Epistle to the Philippians, Paul exhorts Timothy to be an example to the believers "in speech, conduct, love, faith and purity" ( 1 Tim. 4:12). All the gravity of that exhortation Timothy could understand a short few lines after, when his spiritual father wrote to him, "Pay close attention to yourself and to your teaching; persevere in these things, for as you do this, you will ensure salvation both for yourself and for those who hear you" (1 Tim. 4:16). The way of his conduct will not only take away from the power of his preaching but will also set a bad example which could scandalize and lead astray those who are week and uninformed. Paul tried to show that the mature, exemplary believers certainly do not think that they have attained some sort of perfection. The mature believers must somehow pass that to those who look upon them as their models. The imitators need to imitate even with the way they rise after they fall, with their humility when they are rebuked and their 
readiness to repent and change. ${ }^{39}$ Such a mission gives a new seriousness and nurtures the feeling of personal insufficiency and humility in all who function as spiritual leaders in the church. Our example can save many, but it can also set them back and ruin them. May the Lord have mercy upon us, and by the Holy Spirit give us through the Word, Christ's example and the exemplary life of those on whose shoulders we stand to daily keep "being transformed into the same image from glory to glory" (2 Cor. 3:18).

Therefore, in our study of some pertinent passages in the Epistle to the Philippians, we have observed Paul's theology of sanctification. We saw that God promises to finish the good work which He had begun in us, that God is the initiator and effectuator of our sanctification. God wants us to grow in knowledge of Christ, because without the knowledge of Christ as a person and his work, we are unable to grow in Christlikeness, which is the goal of Christian life. Afterwards, we saw that this growth in Christlikeness is inseparably linked to imitating His example, primarily of His attitudes, but also His behavior. Nevertheless, following Christ also means imitating the attitudes and practice of Paul and of those believers who imitate Paul. We are to become their imitators, but also a model for others to imitate as a vertical dimension of believer's transformation into Christlikeness.

\section{Bibliography}

Allison, Gregg, and Chris Castaldo. 2016. The Unfinished Reformation: What Unites and Divides Catholics and Protestants After 500 Years. Grand Rapids. Zondervan.

Bauer, Walter, William F. Arndt, and F. Wilbur Gingrich. 1957. A Greek-English Lexicon of the New Testament and Other Early Christian Literature. Chicago. The University of Chicago Press.

39 In the recent decades, missiologists are becoming aware of the dangers of Christian hagiography, namely "biographical accounts which present the missionary as a person virtually without fault; one who renounced personal desire, ambition, family, friends, and security; whose judgment was always sound; whose integrity was unassailable; and whose behavior was consistently Christlike" (Neely 443). The problem with these accounts is not only that they are false and prove almost disruptive for studying missiology, but they prove absolutely useless for imitation. It is very hard to identify with a spiritual super-hero, who always gets it right. The Bible, on the other hand, is anti-hagiography. It shows us failures of both leaders and Christians in general, like Moses' murder, David's adultery, Peter's denial and Paul's impatience with Mark. Nevertheless, it also shows us Moses' brokenness, David's repentance, Peter's boldness and Paul's later reaffirmation and endearment toward Mark. The reason for this, I presume, is that we need not only examples of success, but also examples of flesh and blood believers who were by God's grace able to come back from their failures. 
Calvin, John, Pringle, John. 2010. Commentaries on the Epistles of Paul the Apostle to the Philippians, Colossians, and Thessalonians. Bellingham. Logos Bible Software.

Crotts, John. 2018. Graciousness: Tempering Truth with Love. Grand Rapids. Reformation Heritage Books.

Foulkes, Francis. 1994. Philippians. U: D.A. et al. New Bible Commentary: 21st Century Edition. Leicester. England; Downers Grove. Inter-Varsity Press.

Hendriksen, William. 1990. New Testament Commentary: Galatians \& Ephesians. Edinburg. The Banner of Truth Trust.

Hendriksen, William. 1964. New Testament Commentary: Philippians, Colossians and Philemon. Grand Rapids. Baker Book House.

Jamieson, Robert, A. R. Fausset, and David Brown. 1997. Commentary Critical and Explanatory on the Whole Bible, vol. 2. Oak Harbor. Logos Research Systems, Inc.

Keener, Craig S. 2009. The Gospel of Matthew: A Socio-Rhetorical Commentary. Grand Rapids i Cambridge. Eerdmans.

Keyes, Dick. 2006. Seeing Through Cynicism: A Reconsideration of the Power of Suspicion. Downers Grove. InterVarsity Press.

Lightfoot, J. B. 1981. St. Paul's Epistle to the Philippians. Lynn. Hendrickson Publishers.

Lincoln, Andrew T. 1990. Word Biblical Commentary: Ephesians. Dallas. Word Books.

Martin, Ralph. 1991. Tumačenje Pavlove poslanice Filipljanima: Uvod i komentar (Original: Tyndale New Testament Commentaries Philippians - An Introduction and Commentary.) Novi Sad. Dobra Vest.

McGrath, Alister E. 1991. In What Way Can Jesus Be A Moral Example For Christians? Journal of Evangelical Theological Society 34/September. 289298.

Moo, Douglas. 1996. The New International Commentary on the New Testament: The Epistle to the Romans. Grand Rapids. Eerdmans.

Neely, Allan. 1999. Saints Who Sometimes Were: Utilizing Missionary Hagiography. Missiology: An International Review 27/4. 441-457.

O'Brien, Peter T. 1991. The New International Greek Testament Commentary, NIGTC, The Epistle to the Philippians. Grand Rapids. Eerdsmans i Paternoster Press.

Reeves, Rodney. 2011. Spirituality According to Paul: Imitating the Apostle of Christ. Downers Grove. IVP Academic. 
Rogers Jr., Cleon L., and Cleon L. Rogers III. 1998. The New Linguistic and Exegetical Key to the Greek New Testament. Grand Rapids. Zondervan.

Schreiner, Thomas R. 2008. New Testament Theology: Magnifying God in Christ. Grand Rapids. Baker Academic.

Schreiner, Thomas R. 2001. Paul: Apostle of God's Glory in Christ. Downers Grove i Leicester. IVP Academic.

Spurgeon, Charles, and Elliot Ed. Ritzema. 2014. Spurgeon Commentary: Philippians. Bellingham. Lexham Press.

Swanson, James. Dictionary of Biblical Languages with Semantic Domains: Greek. Bellingham WA: Logos Research Systems, 1997.

Wallace, Daniel B. 1996. Greek Grammar: Beyond the Basics. Grand Rapids. Zondervan.

Welch, Edward T. 1997. When People Are Big and God Is Small: Overcoming Peer Pressure, Codependency and the Fear of Man. Phillipsburg. P\&R Publishing.

Witherington III, Ben. 2011. Paul's Letter to the Philippians: A Socio-Rhetorical Commentary. Grand Rapids i Cambridge. Eerdmans.

Wuest, Kenneth S. 1997.Wuest's Word Studies from the Greek New Testament: For the English Reader. Grand Rapids. Eerdmans.

Zemek, George J. 2002. The Modeling of Ministers. U: Richard L. Mayhue, \& Robert L. Thomas. The Master's Perspective on Pastoral Ministry. Grand Rapids. Kregel Publications.

Miroslav Balint-Feudvarski

\title{
Posvećenje kroz spoznaju i oponašanje u Poslanici Filipljanima
}

\author{
Sažetak
}

Kroz cijeli Novi zavjet nalazimo poticaje da oponašamo ili slijedimo primjer Krista, Pavla, pa čak i nekih drugih pobožnih ljudi. U Poslanici Filipljanima nalazimo taj poticaj da oponašamo, pripojen Pavlovoj teologiji progresivnog posvećenja. Posvećenje je u Filipljanima prikazano kao suobličavanje Kristu kroz spoznaju Njega, koja dolazi kroz trojni način Božje riječi (apostolskog učenja), unutarnjeg djelovanja Božjega Duha i oponašanja Krista, apostola Pavla i drugih pobožnih primjera. Pokušat ćemo oblikovati biblijsku teologiju posvećenja kroz oponašanje, ograničeni u svojoj analizi na Poslanicu Filipljanima. Prvi dio ovoga 
članka osvrće se na učenje o posvećenju u Filipljanima, s naglaskom na odlomke gdje Pavao izravno postavlja to pitanje: Filipljanima 1,9-11. 27-29; 2,12-16; 3,115. Drugi nas dio članka uvodi u biblijsko učenje o oponašanju, a zatim se osvrće na silaznu spiralu oponašanja: oponašanje Krista (Fil 2,5), oponašanje Pavla (Fil 3.17a; 4,9) i oponašanje Pavlovih vjernih oponašatelja (Fil 3,17b). U zaključku ćemo vidjeti da su oponašanje Krista i Njegovih vjernih oponašatelja sredstvo progresivnog posvećenja, sredstvo koje je i važno i često zanemareno, kako od onih koji bi trebali služiti kao primarni primjeri pobožnosti (duhovni vođe) tako i od onih koji bi se trebali učiti oponašanju. 